\title{
THE PECULIARITIES OF PHYSICAL EDUCATION TEACHERS' PROFESSIONAL TRAINING: FOREIGN EXPERIENCE
}

\begin{abstract}
The article deals with professional training of future teachers of physical education within the context of leading countries, namely the USA, Great Britain, China, Germany, France. The aforementioned countries are not just leaders in economical development; they are also leaders in sports. The analysis of literature resources allowed revealing a number of peculiarities, implementation of which in the process of professional training of teachers of physical education in Ukraine will have positive impact. They are reorientation of professional training, as well as future activity on health protection of students, individual physical development, skills development, big-scale implementation of health-improving systems, non-standard types of motor activity in educational process. This calls for improvement of medical knowledge, health fundamentals, disease prevention, and injury prevention. Increase of the role and duration of teaching practice and implementation of compulsory year-long training at future workplace are of great importance. Taking into account national traditions, historical experience of the development of physical culture in native land, and introduction of national types of motor activity to the curricula have positive effect. The division on two individual stages is common in professional training of teachers. The first one is primarily oriented on theoretical component of educational, while the second one emphasizes practical activity of a future teacher. Along with standardization, independence and autonomy of educational institutions in matters of professional training organization have positive effect in educational process. Governmental support, namely financing of physical training and sports and educational sphere, improvement of material and technical base, plays a key role in the process of professional training of future teacher of physical education.
\end{abstract}

Keywords: professional training, teacher of physical education, foreign experience, school lessons in physical education

\section{INTRODUCTION}

Despite sufficient coverage of the problem of training of future teacher of physical education represented in national education, consideration of other experience in training of physical education personnel, namely in foreign education, is extremely useful.

Gradual integration of Ukrainian education into European educational field calls for unification of the system of specialists training in higher educational institutions, modernization of educational process that would allow students to be mobile in terms of obtaining educational services, would create more possibilities for field studies and training in educational institutions abroad, job placement and obtaining of higher education etc. On the other hand, uneven development of countries, development of new pedagogical technologies in the world, and their implementation in educational process, global 
informatization of society etc. require thorough analysis with purpose of finding positive experience and its further implementation in national educational system. With regards of this, we will conduct an analysis and define certain features of professional training of teachers of physical education in other countries.

\section{THE AIM OF THE STUDY}

The aim is to analyze professional training of future teachers of physical education in leading countries.

\section{THEORETICAL FRAMEWORK AND RESEARCH METHODS}

The peculiarities of physical education teachers' professional training in some foreign countries have been studied. To outline positive aspects of foreign experience and subsequently conduct comparative analysis, the countries should be selected according to a certain criterion. The main criterion has become the participation in the Olympic Games. In particular, we will continue to focus on those countries that are leaders by the results of the Olympics.

The results of participation in the largest and most important world competitions reflect socioeconomic status of the country, development of physical and sports culture, including recognition and significance of physical education teachers. World leaders in physical culture and sports development are the USA, China, Great Britain, Germany and France. The peculiarities of physical education teachers' professional training have been considered by such scholars as K. Bain (2004), T. Dereka (2016), O. Haiduk (2014), T. Kharchenko (2007), V. S. Man (2008) et al.

Thus, taking into account significant achievements of scholars in teacher education in the world, we consider it necessary to conduct a comparative and pedagogical analysis of physical education teachers' professional training in developed countries of the world and in Ukraine in order to identify its common and different features. This, in turn, will reveal prospects and outline ways to improve professional training of physical education teachers in Ukraine.

\section{RESULTS}

When analyzing foreign education, it is important to note that it is also in the state of reformation and modernization. It is reflected in the reconsideration of various terms and notions, setting of new goals and tasks for physical education, search of non-standard and innovational way of their solution, etc.

Reorientation of school curriculum of physical education in the USA can be viewed as an example (Maurer, \& Jordan, 2006). Thus, at lessons of physical education in American schools, the priority of learning and training in various kinds of sports, competing, achieving big results is gradually changing to personal individual physical development, improvement of psychophysiological condition of students, preparedness for future profession etc. This, in its turn, calls for significant reorientation of occupational training of future teachers of physical education. Thus, future teachers of physical education must be better aware of the issues of health protection, know modern health protection technologies, have sufficient level of knowledge and skills in organization of student's optimal motor activity, etc.

According to T. Dereka (2016), characteristic features of professional training of future teachers of physical education in the USA are differentiation and individualization of education within personal approach, profound practical orientation of each training course. Another important feature is close interdisciplinary connection, which is reflected in the formation of a future teacher's complex competences that are based on integration knowledge 
and skills obtained from various disciplines. In general, students form their own education trajectory that lies in independent determination of academic workload, selection of courses in various types of motor activity, forms and methods of optimization of classes. During professional training attention is paid to close correlation of theoretical and practical training.

Problem-based learning, methods of modeling, role games and others are widely used during training. Discussion becomes of great importance during educational process; each student must express his own point of view on the matter of research. In the process of training of future teachers of physical education, special attention is paid to teaching practice that lasts 14 weeks. Increased duration of teaching practice allows having it annually, gradually moving from passive observation to its active form - personal lessons in physical education. Moreover, a year-long probation period, which future teachers of physical education must undertake at workplace, is an important part of a teacher formation (Bain, 2014). Probation help young specialists to have more gradual transition from studying to active professional activity, facilitates adaptation, decreases chances for crises that often accompany young specialists.

Analyzing foreign experience, we will emphasize peculiarities of providing physical education in comprehensive schools of Great Britain. Similar to Ukraine, physical education is a compulsory subject included to all curricula of schools in Great Britain. Besides compulsory 3 academic hours per week, extra-curricular and optional classes of physical education are widely used. Peculiar features of school physical education are expansion of types of sports, implementation of non-traditional types of motor activity in educational process, giving students more opportunities to choose kinds of sports and physical exercises that student can be engaged into during lessons of physical education. Physical exercises by interest and more promote increase of lessons efficiency and have positive impact on students' desire to do extra-curricular physical exercises.

Special attention is paid to training of teachers able to support high level of physical education at school. Along with conventional forms of lessons organization in Great Britain variable education is widely used i.e. combination of theoretical and practical training throughout the year. At the start of semester, student study compulsory subjects, then they strengthen the results by having field studies. Appointment of teachers responsible for a group (tutors) helping students study better and providing connection between students and teaching staff is widely used in the process of professional training (UK Government, 2012). Ukraine has a bit similar form of assistance in education in the form of tutorship. Similar to education in the USA, problem-based learning, use of role game, dealing with non-standard situations are also realized in Great Britain. Another important part is compulsory 14 -week teaching practice and a year-long probation period at workplaces.

Paying attention to experience of China, we may point out that the entire sphere of physical education and professional training of physical education staff are a primary concept of state's policy. In general, the sphere of physical education in China is aimed at preparation of healthy, competent youth with high level of working ability and vital activity (Man, 2008). A peculiar feature of Chinese physical education is preservation of historicallyformed kinds of physical education. An example of such types may be "Qigong" Chinese gymnastics, health systems (taitszi-tzuan) etc. An important task of physical education for school students is to promote optimal physical development, to form important social qualities (discipline, responsibility, honesty, fairness etc.), to develop basic motor skills, to attract interest and evoke love to sports. Moreover, special attention is paid to school sports. Thus, it has been acknowledged on the official level, that a school sport is the basis for state's sport reserve. 
Stringent requirements are set for training of teachers of physical education. Besides general responsibilities of a teacher to give basic knowledge in sanitary norms, to stimulate students' interest to personal health and development of personality, to teach basic kinds of sports, teacher's professional responsibilities also include others. Thus, a teacher should be able to hold sports festivals, teach selective courses, prevent various diseases, namely eating disorder, visual impairments, various infections etc. For this, the course of "Health Protection" is envisaged in the process of training of future teachers of physical education in China. In this course, students obtain knowledge in methods of treatment of illnesses with the help of various Eastern health-protection systems (Man, 2008).

Germany has significant experience in training of future teachers of physical education. Despite the fact that modern education is characterized by certain standardization, there is no unified state system of professional training if teachers of physical education in pedagogical education of Germany (Haiduk, 2014). Each territorial unit (land) that is part of the country, has its autonomy, independently regulates educational policy and sets own rules of educational process (Haiduk, 2014). Namely, each land forms requirements to content of education, terminology of professional training, forms, content, final evaluation, and qualification that students gain after completing course of studies.

Another peculiarity of training of teachers of physical education in Germany is a distinct division into two stages. The first one is based on studies at an educational institution that lasts for three years and end with taking of the first state examination. The second stage is connected with two-year field studies (referendariat) after completion of which students take final state examination. Staging of professional straining of is outlined in the standard (Kultusminister Konferenz, 2004), according to which future teachers of physical education obtain basic occupational competences at the first stage. At the second (practical) stage, future teachers learn to apply theoretical knowledge (Haiduk, 2014).

Further on we will analyze training of teachers of physical education in France. It is rather similar to the German one by its two-stage system. Thus, five-year term of studies is divided into two parts. Peculiar feature of training of teachers of physical education is that student first complete three-year specifically scientific training and are awarded the diploma of licentiate (Kharchenko, 2017). Next stage is studying at university institutes for teacher training. During specialized two-year studies, students have profound specificallyscientific training, psychological and pedagogical as well as comprehensive training. Peculiar feature of the second stage is teaching practice that applied during the two-year period of studies (Legras, 1995).

Besides general and specific competences that students acquire during five-year course of studies, it is important to prepare future teachers of physical education to individual work. Peculiar feature of such work at school is that a teacher of physical education, at first, observes each student, evaluates individual skills and inclinations, and determines talents of the teenagers. Later, based on the results, teacher helps his student to make individual plan of orientation that enables the student to determine his own direction of studies.

Having analyzed peculiarities of training of future teachers of physical education in countries that lead in both educational and sports aspects, we will move on analyzing possible implementation of positive experience in education of Ukraine. When developing pedagogical system of training of future teachers of physical education it is important that it should be effective and efficient, should take into account modern aspects, namely, it should be of forward-looking nature. Fast pace of educational system reformation, implementation of modern technologies, increasing the level of communication between the 
parties of educational process through social networks set new requirements to future teachers, namely teachers of physical education. At the same time, orientation on current state is insufficient. A four-year lag in training of bachelors calls for prognostication and forecasting for several years ahead of tendencies of education development.

Based on this we see two efficient ways to improve quality of training of teachers of physical education. The first one is training of teachers of new formation who are always oriented on self-development, self-improvement, and improvement of personal professional level (Pavliuk et al., 2017). The second one is taking into account positive experience of the countries that have better achievements in scientific and educational areas. Given the fact that Ukraine gradually integrates into the leading world community, the experience of these countries is extremely valuable.

The analysis of foreign experience allowed revealing a number of important features related to professional training. Namely, it is possibility for students to select. The selection may not only refer to subjects, but to courses, level of knowledge; students can create their personal health protection programs. The notion of selection in education has rather broad definition. It enhances inner motivation to studying, responsibility etc.

We consider increase of the value of teaching practice to have a positive impact. This gives a chance for future graduates to adapt to future profession better, to shorten the term and facilitate adaptation to activity of a teacher of physical education. Implementation of compulsory year-long probation period at future workplace is important.

Humanization of education, reorientation of professional training and future activity to individual physical development, students' health protection, implementation of health protection systems and non-standard types of motor activity in educational process also play an important role. In its turn, it calls for improvement of medical knowledge, health fundamentals, disease and injury prevention. Taking into account national traditions, historical experience of the development of physical education in native country, inclusion of national types of motor activity to curriculum are important.

At the same time, the division of higher educational process into two stages (theoretical and practical) is rather difficult to be done under conditions of national education. It is produced by the fact that educational establishments in Ukraine do not have close communication and correlation. In fact, each higher educational establishment independently builds the strategy of its development. Our country's higher educational establishments should also have autonomy not only in matters of organization of educational process and professional training, but also in financial aspects. Governmental support, namely financing of physical training and sports and educational sphere, improvement of material and technical base, plays a key role in the process of professional training of future teacher of physical education

\section{CONCLUSIONS}

The analysis of foreign experience showed significant attention to training of future teachers of physical education being paid not only by educational establishments but also by the state.

In the course of theoretical analysis, a number of features of professional training have been revealed. Realization of these features has positive impact on national education, namely, enhanced possibilities for selection during the course of studies, increase of the role of practical training including teaching practice, expansion of competences of a teacher of physical education in medical knowledge, health protection, health protection systems etc.

Perspectives for further studies are seen in studying the peculiarities of physical education teachers' professional training in leading European countries. 


\section{REFERENCES}

1. Bain, K. (2004). What the best college teachers do. Cambridge, MA: Harvard University Press.

2. Dereka, T. (2016). Profesiina pidhotovka fakhivtsiv fizychnoho vykhovannia u SSHA. Neperervna profesiina osvita: teoriia i praktyka, 1-2, 71-76.

3. Haiduk, O. V. (2014). Osnovyie etapy professionalnoi podgotovki uchitelei fizicheskoi kultury v vysshykh uchebnykh zavedeniyakh Germanii. Vestnik Udmurtskogo universiteta. Seriia "Filosofiia. Psikhologiia. Pedagogika", 1, 66-69.

4. Kharchenko, T. (2007). Profesiyna pidgotovka vchyteliv pochatkovoi ta serednyoi shkil u suchasniy Frantsii. Visnyk Zhytomyrskoho derzhavnoho universytetu imeni Ivana Franka, 32, 61-65.

5. Kultusminister Konferenz. (2004). Standards für die Lehrerbildung: Bildungswissenschaften (Beschluss der Kultusministerkonferenz vom 16.12.2004). Abgerufen von https://www.kmk.org/fileadmin/Dateien/veroeffentlichungen beschluesse/2 004/2004_12_16-Standards-Lehrerbildung.pdf.

6. Legras, J.-M. (1995). Des IUFM pour l'unification de la formation des maitres. Cahiers pédagogiques, 335, 37-38.

7. Man, V. S. (2008). Osobennosti sistemy hosudarstvennogo upravleniya fizicheskoi kulturoi i sportom v KNR. Slobozhanskyi naukovo-sportyvnyi visnyk, 4, 217-221.

8. Maurer, M. R., \& Jordan, P. J. (2006). Steps to successful physical education. Teacher education workshop: physical educator, 63 (1), 53-56.

9. Pavliuk, O. S., Chopyk, T. V., Antoniuk, O. V., Pavliuk, Ye. O., Soltyk, O. O., \& Biliński, J. (2017). Pedagogical technology of physical education teachers' professional self-improvement. Science and education, 4, 101-106.

10. UK Government. (2012). Education system in UK. Retrieved from https://www.gov. uk/government/uploads/system/uploads/attachment_data/file/219167/v01-2012ukes.pdf. 